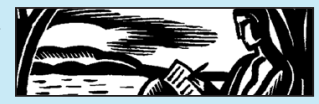

\title{
Cytoarchitecture: Digital Dismembering and Remembering in Cyberspace
}

It comforts me that endings are thus formally unappealing to me-that more than beginning or ending, I enjoy continuing. ${ }^{1}$

\section{Emma Newport}

University of Sussex

\section{ABSTRACT}

Between 2012 and 2017, a contributor to Mumsnet, a popular parenting forum online, began recording a third-person account under the pseudonym IamtheZombie, covering first her divorce and then her experience of cancer. In January 2017, IamtheZombie died. Preserved by MumsnetHQ, the threads form a tissue of posts: a text-culture that explores para-sociality between the living and the dead. Building on existing scholarship on digital life writing, on the afterlives of digital footprints and on recent work in the fields of memory studies, computing and neurobiology, this essay offers a new interdisciplinary framework for describing relationality in life writing on illness, dying and death: cytoarchitecture.

Keywords: life writing, death, digital, posthuman

\section{BODILESS MOURNING}

Grief is abstract. It is intangible; it is often about something no longer there. Marking a desire to recollect someone absent, roadside flowers, stuffed toys on gravestones and candles in windows silently and publicly imprint loss onto the landscape. These sorts of objects manifest the intangibility of mourning and at the same time become a synecdoche for the person being mourned. Recollection implies remembering and 
reconstituting. Makeshift shrines may be accompanied by handwritten epitaphs, often epistolary or apostrophic in form, as letters and notes to the recently deceased are tucked in amongst the material objects of sited mourning. ${ }^{2}$ Such temporary, informal memorials offer fleeting encounters to passers-by who wonder what happened, who has been affectedand so are perhaps invited to grieve their own mortality. Choosing to pause when passing a memorial can be as much an act of self-reflection as it is one of empathy.

As Candi Cann has noted, the most curious aspect of public memorialisation is 'the movement toward memorialization without the body. From spontaneous memorials to memorial services (as opposed to funerals), there is a key element missing: the dead body'. ${ }^{3}$ She suggests that

Bodiless memorials-whether they are a spontaneous memorial at the site of death, or a service without the corpse-are a remembering and celebration of the body without the body. In short, a bodiless memorial is a disembodied memorial for the body. ${ }^{4}$

The memorial allows those who encounter it to remember in the absence of the dead. Such a practice has a long history, particularly in the remembering of the war dead. ${ }^{5}$ For example, both world wars resulted in nameless bodies of soldiers being buried in anonymous war graves in France, which contrasts with the bodiless names engraved onto war memorials found in British villages, towns and cities. The empty tomb of the Cenotaph in London, finished in 1920, is perhaps the most famous and imposing example of modern bodiless memorials. However, Katie Trumpener highlights some of the problems with such an act of memorialisation, particularly in the way in which it fundamentally alters the act of grieving, and so can change the particular kind of remembrance associated with grief. ${ }^{6}$ In her article, Trumpener surveys the varying criticism, both contemporary and more recent, levelled at these bodiless memorials. Whilst they proved popular, with thousands of civilian mourners leaving wreaths at the yet-to-be-completed Cenotaph during the victory parade in 1919, this kind of official monument-making 'elicited repression rather than collective memory, perpetuating the wartime disjuncture between combatant and civilian experience.'

One form of recovery has become the spontaneous and informal memorial site, which is not mediated through institutions such as the state or church. However, these temporary sites continue to raise the same fundamental question of how to deal with bodilessness when memorialising the dead. According to Cann:

There is no space for grieving because without the encounter of the corpse itself, there is a fundamental denial of death, underscored by the missing body. The dead body has both figuratively and literally gone missing from 
death; but with this dis-placement of the body, death itself has become denied, and grieving itself becomes marginalized. ${ }^{8}$

The problem of bodiless mourning is intensified when death migrates online. When Internet users experience bereavement amongst a digital friendship group whom they have never met in person, the denial of death can sometimes seem callous-other users may demand to know 'Is this true?' As such, the grief process may become marginalised, for instance when arguments between users derail the thread or when posters respond to the news with the acronym for laughing, LMAO (laughing my ass off). Is it a laugh of disbelief? Of delight in another's misfortune? Now, in addition to the informal but material sites of memorialisation, such as flowers and candles at the site of a road traffic collision, we have online memorial sites in which the body is always displaced, such as Facebook's memorial pages, which are created through converting a deceased user's page. ${ }^{9}$

\section{METAPHOR AS A STRATEGY FOR NAVIGATING DIGITAL LIFE WRITING}

These kinds of issues are not limited to the digitisation of mourning: they intersect in important ways with the digitisation of life writing practices. More generally, auto/biography dismantles the notion that the human mind and memory act as a repository for the self, which has historically been understood to be a discrete entity; this dismantling of such imagined certainties of discrete selfhood has resulted in methodologies that are lively and discursive in principle and practice ${ }^{10}$ Culture, memory, language, mind, and perception co-produce identities in relation to others. As Aimée Morrison acknowledges in her inquiry into the Facebook status update as life writing, digital life writing "poses a kind of limit case of autobiographical theory and criticism, at once terrifying and compelling in its sheer scale and its wide-open popular production'. ${ }^{11}$ Anna Poletti's recent essay on periperformative life narrative acknowledges the scale of this problem as she contemplates the 'large array of practices', including online and offline life writing across a variety of media, that has led to the 'destabilizing of critical terminology', to which she adds 'collage' as a useful strategy for 'nontraditional authors of life narrative'. ${ }^{12}$ It is, then, as Anna Poletti and Julie Rak note, useful-even necessary-to participate in interdisciplinarity in order to generate novel methods of describing and understanding these nebulous online auto/biographies. The necessity of interdisciplinarity as a solution to digital problems has been identified in disciplines that overlap with life writing: for example, Brian Lavoie and Lorcan Dempsey, though predominantly writing for an audience of 
librarians and archivists, raise important questions about the delimited nature of

[p]reserving our digital heritage [which] is more than just a technical process of perpetuating digital signals over long periods of time. It is also a social and cultural process, in the sense of selecting what materials should be preserved, and in what form; it is an economic process, in the sense of matching limited means with ambitious objectives; it is a legal process, in the sense of defining what rights and privileges are needed to support maintenance of a permanent scholarship and cultural record [...] And perhaps most importantly, it is an ongoing, long-term commitment, often shared, and cooperatively met, by many stakeholders. ${ }^{13}$

In this article, I offer a further strategy to describe and navigate the alarming heterogeneity and scale of digital life writing. This novel paradigm emerges from Avril Maddrell's approach to mapping memory and emotion: neurobiological models offer a new way of synthesising life writing, memory and identity formation in online spaces. ${ }^{14}$ Maddrell makes the case that describing emotions in virtual and in embodied-psychosocial spaces necessitates grappling with the biological as well as the cartographical in locating and describing the spatialisation of emotion; she arrives at the notion that the brain is the embodied-psychological space of emotion and memory. The brain is fleshy material and it is an intangible series of synaptic impulses. As a site of study, the structure of the brain itself opens up tantalising prospects for developing ways of dealing with what Morrison has rightly pointed out is the challenge for scholars of corralling the multiplicity and nebulousness of digital life writing.

Neuroanatomy utilises cartographic principles in human brain mapping. For example, in the description of the cytoarchitecture, or cell structures, of the cerebral cortex, the language of 'landmarks' and 'architectonically defined borders' points to the ways in which the cartographical intersects with the biological when describing the structure and functions of the cerebral cortex. ${ }^{15}$ Neurobiologists posit that long-term memories live at and are transmitted between synapses, which are the spaces where impulses pass from one nerve cell to another. It appears that lasting memories are dependent on a strong network of such neural connections and that memories weaken or fade if the synapses degrade. ${ }^{16}$ For those working on the interface between the virtual and 'real world', this understanding of biological memory is influencing new advancements in digital data recording and retrieving. Interdisciplinary approaches have helped researchers working in the nexus between cell structures and computer memory systems but also, more importantly, have invited new thinking about the role of language and semiotics in the interfaces that exist between human and machine. ${ }^{17}$ 
Working in the field of software studies, but thinking in broader ways about role of rhetoric and narrative in the life sciences, Richard Doyle makes the link between the way in which DNA is understood as being the building blocks of life and as functioning as a form of coding, which is both equivalent to and dependent on the coding that underpins software. ${ }^{18}$ In other words, the conceptual framework, or way of seeing and understanding the building blocks of life and of seeing and understanding computing software is analogous. At the same time, decoding DNA is dependent on computer software code: the ability to understand and to process the former is dependent on the latter. He argues:

The transmission, passage, and communicability of language, therefore, become something other than affair of meaning or information; they become something more like ballistics or contagion, the transmission of an effect across bodies of discourse and across bodies. DNA in its figuration as a 'language', ironically provides us with a metaphor for thinking of language as a contagion: the passage from deoxyribo-nucleic acid to proteins passes through and in a body, and it is an elision of this body, the displacement of the organismic 'productions' of a living body, that characterizes the history of molecular biology and allows the communications of the future of a 'genetic code' that seamlessly and automatically transcribes and translates the DNA 'word'. This hermeneutical paradigm of DNA transcription and translation systemically overlooks the force of this activity, its performance, its embodiment. ${ }^{19}$

By considering how rhetorical devices or, as Doyle describes them, 'bits of software', function as 'technologies of language that act on and in bodies, cultures, and sciences', Doyle points to the disciplinary and conceptual permeability between the study of semiotics, molecular biology and computing software. ${ }^{20}$ Wendy Chun builds on Doyle's work on the 'many metaphorical uses of software', and suggests that, in order to think about the intersections of cybernetics and genetics, 'software' provides both the language and the mechanism to do so. ${ }^{21}$ Chun examines the complex confluence of the biological and the technological in the evolution and nature of computer memory. Significantly, as her thesis unfolds, Chun coopts the language of the 'undead' and 'daemonic' to describe the ephemerality of computer memory and the digital's capacity to regenerate and degenerate. ${ }^{22}$ Where Doyle sees the vitality of the ways in which language and bodies are coded and embodied, Chun sees the possibility of a postvital and haunting in-betweenness.

Through understanding how the biological affects the technological, we may, therefore, examine the inverse of something familiar to life writers, who already understand how new communication tools 
impact the ways by which life narratives are constructed, communicated and recalled: for example, the implications of digital technologies on self-description from the perspective of narrative theory. ${ }^{23}$ Krista Roberts acknowledges the struggle, and necessity, of life-narrative scholars to investigate the metadata of both person and machine, and how to account for and conceptualise such posthuman collaborations. ${ }^{24}$ Furthermore, Laurie McNeill suggests that social networking sites, (SNSs) such as Facebook, produce 'algorithmic auto/biograph[ies]' through algorithmically-constructed tableaux of updates and 'Stories', and through algorithms 'telling users about themselves while telling the site and its advertisers about the users'. ${ }^{25}$ This, posits McNeill, is 'collaboratively, if not consensually, coproduced in ways that suggest that the subject of Facebook is the product of a posthuman process'. ${ }^{26}$ There is an increasing need for critical methodologies and terminology that are capable of synthesising not only the nuances of relationality online but also of addressing life writing that may exist on and offline and in plural but potentially interconnected digital media across a variety of platforms: material that is even coproduced-often tacitly, maybe non-consensually-between people and machines. Various strategies have been developed, including Poletti's use of the term 'collaging'. The concept of 'collage' introduces important ideas of automediality; in addition to providing strategies of resistance for nontraditional authors, 'collage' helps scholars to address the diversity of digital life writing materials. Nonetheless, the idea of 'collage' is too fixed, too static, to articulate the growing and shrinking of online connections and interactions and the changes-for good or illthat occur in the ongoing networking of life writing that takes place on single platforms, such as Mumsnet, or between multiple platforms across the internet. By contrast, Whitlock and Poletti's term, 'auto-assemblages', does speak to the dynamism of multiple methods of self-representation in cyberspace, which are 'the result of ongoing selection and appropriation of content across several modes brought together into a constellation for the purpose of self-representation or life narrative'. ${ }^{27}$ Their work also articulates what the automation of the algorithm brings to authorship and life writing online. ${ }^{28}$

Scholars have acknowledged that the 'affordances' of a digital interface and the technological tools used to access it produce novel possibilities for identity construction. ${ }^{29}$ This, in turn, shapes and is shaped by the social platforms through which users might construct themselves. Significant work in the field of auto/biography has been undertaken to explore how interstitial interplays of offline and online identities inform and complicate identity construction. ${ }^{30}$ For example, 'anchored' and 'unanchored' describe different types of virtualisation that might take 
place in the construction of online relationships. A non-anonymous or 'nonymous' platform like Facebook invites people to use their real names and communicate with people with whom they have offline or 'anchored' relationships. ${ }^{31}$ At the other end of the scale are anonymous confessional sites, such as Whisper. By comparison, sites like Mumsnet, Reddit, 4 Chan and Secret Confessions (4Chan and Secret Confessions permit both anonymous and pseudonymous posts) are pseudonymous fora that include message boards on which people post statements, questions and anecdotes. Through the life writing that takes place online in these digital spaces, participants may encounter 'unanchored' virtual sociality: friendships formed and maintained entirely online through social media and online gaming. ${ }^{32}$ However, whilst Alessandra Micalizzi asserts that digital identity is formed in relation to online communities in ways that parallel offline communities, what is less clear is how to describe and understand two overlapping and uniquely digital experiences: firstly, the pseudonymous community and its formation and, secondly, the effects on community and identity that death produces. ${ }^{33}$ This is a key point in which offline and online modalities of community diverge, as there are ways in which digital ongoingness, or digital afterlife, to use the posthuman terminology, disturbs our understanding of the formation of the individual self in relation to community. The specific context of online networks and the role that life writing has in imagining and constructing virtual friendships leads to a larger question of what happens when a member of the online network dies but the network persists. Using a case study in the life writing on the online forum Mumsnet, I consider how the life writing dialogues that form these networks persist beyond offline death, with consequences for narrative, memory and recollection, and the formation of online identity. I posit that the concept of cytoarchitecture is a useful addition to the growing critical terminology being developed to describe the novel life narratives formed online, and can be patched into life writing's critical thinking about death.

Using biological metaphors to articulate the intersections and interplay between digital life narrative, memory, death, memorialisation and emotion-especially grief-is a compelling strategy. Susan Sontag was one of the first to draw critical attention towards the metaphorisation of illness. As Sontag notes:

\footnotetext{
Any important disease whose causality is murky, and for which treatment is ineffectual, tends to be awash in significance. First the subjects of deepest dread (corruption, decay, pollution, anomie, weakness) are identified with the disease. The disease itself becomes a metaphor. Then, in the name of the disease (that is, using it as a metaphor), that horror is imposed on other things. The disease becomes adjectival. ${ }^{34}$
} 
In relation to illness narratives, Arthur Frank adapts Sontag's metaphor of dual citizenship to consider the 'inbetween-ness' of 'remission society', suggesting that 'members of the remission society do not use one passport or the other. Instead, they are on permanent visa status, that visa requiring periodic renewal'. ${ }^{35}$ Such inbetween-ness of remission recalls Chun's identification of the regenerative and degenerative possibilities of cyberspace, and the ephemerality of computer memory. The interstitial which, when referring to anatomy, describes the fine connective tissue lying between the cells of other tissue, is thus vital to the understanding of the multiple occurrences of 'inbetween-ness' that occurs in digital life narratives, which are arguably intensified in accounts of illness. ${ }^{36}$ Cytoarchitecture, with its synapses and cell structures, becomes a highly useful metaphor with which to describe and navigate the complex networked relationality and 'inbetween-ness' of cyberspace as it is ideally suited to describe the complex posthuman ecology of digital life narrative. Whilst auto-assemblages is an important descriptor of this key aspect of the posthuman conditions of life writing online, the paradigm of cytoarchitecture works to describe what happens in the 'spaces between-whether between body and text, experience and audience, self and other, past and present, life and fiction, text and image'. ${ }^{37}$ To Lara Feigel and Max Saunders's list we may add human and machine, healthy and ill, living and dead. These kinds of interstitial spaces have been articulated through various biological metaphors; for example, Audre Lorde engages in the 'cracking and eventual re-formation of language [that] is emblematic of Lorde's larger enterprise in bridging artificial distinctions between the journal entry as the genre of "body" and "emotion" and the essay as the genre of "mind" and "intellect". ${ }^{38}$ However, the novel biological metaphor of cytoarchitecture helps to frame in new ways a very familiar question: What remains of us when we die?39 To this old question we may add some new ones: how is remembrance and recollection effected in cyberspace? In what ways do we remain living through a corpus affected by digital febrility? In this article, therefore, I examine the intersections amongst life writing, death studies and memory studies in the context of end-of-life writing on an online forum.

\section{'IAMTHEZOMBIE': MUMSNET AS CASE STUDY}

Mumsnet, a pseudonymous, UK-based online parenting forum, is a category of social media that is distinct from SNSs, such as Facebook. As an online community, Mumsnet provides a platform for an intimate public, where posters' friendships are mediated through pseudonyms that create unstable networks of the falsely familiar. ${ }^{40}$ Posters may disappear from a 
thread or reappear in an altered form after a name-change. ${ }^{41}$ Posters can de-register and later re-register under a new identity or resurrect an older one. Contributors may begin or add to multiple threads, revealing aspects of their lives that may be partly fictionalised to prevent 'outing' in real life. Alternatively, identities may be wholly fictionalised, for instance by trolls (trolls on Mumsnet are those who introduce false stories to the site).$^{42} \mathrm{On}$ Mumsnet, users forge a digital sociality through sharing life narrative, which is mediated by giving and receiving emotional support and advice in online posts. An example of the way in which the site offers a space for sociality is in the use of emojis depicting food and drink to demarcate online toasting of events, such as birthdays, success and loss; metonymic sociality also occurs when food emojis substitute body parts to represent sex acts. ${ }^{43}$

One form of support that is commonly given and received centres around illnesses, including cancer, which has led to some terminal cases and the loss of a user for whom the wider online community of Mumsnet has grieved. Couser points to the significance of online spaces and the massively expanded 'new modes and media':

Beyond the realm of print stretches the vast expanse of cyberspace, which hosts blogs, online support groups, and other forms of self-representation. In addition, social media like Facebook and Twitter offer venues in which people with various medical conditions can issue running accounts of their welfare in real time, giving new simultaneity and immediacy to illness and disability narrative. ${ }^{44}$

Users can be uncertain about the health status of other users and may continue to engage with a deceased person in ignorance of that poster's death. Others may deliberately choose to write to a dead user as though they are still alive, which can heighten the ambiguity for users as to whether someone is dead or alive. The virtual environment makes unclear the gap between living and dead, creating new challenges in navigating the death process.

Although there are a number of Mumsnet posters who have recorded their experiences of illness, and who have been mourned online when they have died, such as Earthmotherimnot and TwitterQueen1, for the purposes of this article, I will focus on a user called IamtheZombie and how her end-of-life writing evolved into a spontaneous virtual commemoration. The user history of Candy Orr, the woman behind IamtheZombie, spans from November 2010 and continues until January 2017; she initiated her zombie persona in 2012. IamtheZombie's posts chart her divorce, illness, house moves and the marriage of her son. ${ }^{45}$ She chose to write in the third person when using the IamtheZombie pseudonym and this sometimes caused confusion amongst other Mumsnet users. To 
provide an explanation, IamtheZombie gathered the parts of her story in the thread 'Why Zombie is Zombie-the backstory (183 Posts)'.

IamtheZombie Mon 30-Dec-13 17:59:14

Zombie is periodically asked what her backstory is and why she speaks in the third person. Bits of the story are scattered around various parts of the site (as are a few of her limbs). The story is fairly long and a bit complicated. She's therefore putting this thread here so she can simply refer people to it rather than trying to tell it all again.

She has found 2 posts that between them tell pretty much the whole story.

The first one is her initial reply on a Zombie appreciation thread started by [another poster] in September 2012. The second one is the OP [original post] of a thread Zombie started in September 2013 which brings the story pretty much up to date.

IamtheZombie Sun 16-Sep-12 12:59:41

Oh, gosh. blush blush blush

Zombie did not expect to ever see a thread like this. She hardly knows what to say. She does realise that [...] some people are annoyed by her posting style. She will therefore now step out of character to answer your questions.

Once upon a time I was a relatively boring MN poster. I used to enjoy the OFRS [oh fuck rucksack] threads and one day I thought that having a 'real' zombie join them might add a new dimension. ${ }^{46}$

Thus IamtheZombie was born. I chose to have her post in the third person for a couple of reasons. First, it would instantly set her apart from the real people.

Second, I figured that a zombie would be a bit confused as to whether she was the person she used to be or was really a zombie. Third person speak was my way of trying to show this confusion.

A zombie is a creature of paradox. It is 'familiar and alien, alive and dead, human and non-human', often exhibiting an 'almost robotic torpor'. ${ }^{47}$ The zombie is an interstitial being, unsure whether she is who she used to be: an embodiment of the 'inbetween-ness' of remission society. The adoption of an undead pseudonym to deal with divorce, disease and death offers the writer a new method of exploring through the persona's perceived 'confusion', as IamtheZombie describes it, the real anxiety of trauma and its consequences. When IamtheZombie describes this process as regathering 'bits of the story [that] are scattered around various parts of the site (as are a few 
of her limbs)', the fractured narrative and fragmented self are suggested through metaphors of the crumbling body of the zombie. IamtheZombie reimagines herself as something that is resistant to feeling physical and emotional pain, is uncomprehending and a creature defined by its determined and ongoing lurch forwards. Later, the metastasis of IamtheZombie's cancer increasingly tyrannised her body, amputating a foot, plucking out hairs, sucking the flesh to the bone until the ridges of her cheeks stood proud and her eyes sat deep in her skull. Her body became unfamiliar and estranging, something recalcitrant and chaotic. Real life meshes with unreal life; the undead triumph over real death. ${ }^{48}$

Whilst it is clear that IamtheZombie's methodology transfers the horror of her life experiences onto other things, her metaphorising of the body is more ludic: IamtheZombie performs as a zombie. She is iconic and ongoing both in the zombie's cultural significance and in what the zombie represents-forever between alive and dead, and remarkably difficult to defeat. ${ }^{49}$ The zombie is not just a straightforward embodiment of cancer's tyranny, although it does, of course, serve this function: the zombie's undead persistence also associates it with an ongoingness inherent in digital life writing.

For several months I used my normal nickname for most of my posts and only changed to Zombie to play on relevant threads.

Then, last November, life went tits up. Actually what I mean by that is that it went tit off. I was diagnosed with an aggressive breast cancer. I had anmastectomy [sic] in November.

In December I learned that although the surgery had been a complete success in that they were as sure as they could be that they had removed all the active cancer (lymph nodes clear, no vascular invasion and a clear margin around the tumours), because the tumours were so aggressive (and were hormone positive and HER2+), I would need the full spectrum of adjuvant therapies. ${ }^{50}$

At this point, Zombie started to become part of my coping mechanism. She provided a harmless distraction from what was going on in RL [real life].

I had chemotherapy from mid-January to early May. I had radiotherapy from late May to mid-June. In July I started an 18-cycle course of Herceptin which I will finish next July. I am also on Arimidex for 5 years. Arimidex can potentiate osteoporosis so I also have to take other medications to try and counter that possibility.

By late January / early February I had abandoned my other nickname and was a full time Zombie. This year I have also lost my MIL [mother-in-law] in April and more recently my Godson whose funeral I attended last week. Zombie is my lifeline at times. 
Becoming an online zombie cemented its appeal when IamtheZombie encountered real-world death amongst her family and friends. The idea of the identity as a 'lifeline' encompasses not only its function as rescue or support, but also implies that one goes on-both in the sense of not giving up when facing adversity and in the sense of continuing an alternative existence online. Online has capacity for continuation. Words remain online as digital remains which other internet users can continue to read and respond to. The dead are still speaking to online users in old posts and podcasts, YouTube videos or Instagram stories.

When contemplating how 'To Reckon with the Dead', Pascale-Ann Brault and Michael Naas ask: 'How do [...] we let the dead speak?' ${ }^{51}$ To try to answer this question in their introduction to Derrida's The Work of Mourning, Brault and Naas turn to the Derridean idea that 'the substitution of the name for the body, the corpus for the corpse appears to be the only chance the dead have left' ${ }^{52}$ Derrida describes Foucault's text A History of Madness as asking questions that leave the text 'in suspense, holding its breath—and, thus, keeps it alive'. ${ }^{53}$ In contrast, Sarah Manguso, as a life writer, argues that her sense of aliveness is embedded in her diary-writing:

I started keeping a diary twenty-five years ago [...] The diary was my defense against waking up at the end of my life and realizing I'd missed it. Imagining life without the diary, even one week without it, spurred a panic that I might as well be dead. ${ }^{54}$

Here, the diary becomes a metonym for a life being lived. The act of writing is essential to the act of living. The body as book and the narrative as living reimagines the corpse and corpus relationship; in Manguso's work we encounter le corps (the French word for 'body', something vital instead of cadaverous) et le corpus.

Eventually, though, Manguso's desire to document constantly as a means of resisting an ending became so strong, so urgent, that the diary as metonym for existence began to obscure the tenor of her life. Her pull into the ongoingness of diary-keeping meant that, after two and a half decades, it was ' 800000 words long. [She] didn't want to lose anything'. ${ }^{55}$ The fear of loss became a stultifying force. Choked by volumes of words too numerous to manage and even more impossible to print, Manguso was struck by how estranged she felt when re-reading her diaries. In her fear of loss, in her anxiety-ridden belief that to stop writing her life would mean that she was somehow no longer living, Manguso came to realise that she was not maintaining the act of living through life writing but had, instead, created her 
own monolith, weighty and unwieldy. What ultimately became Ongoingness: The End of a Diary is sparse and ludic, its ninety-five small pages punctuated by fragments of text that are interspaced with (often much) larger sections of white paper. She does not merely extract highlights: she distils her prolix diary into something vital, and miniature. Manguso did not find the same potential for ongoingness that Derrida identifies in the voluminous corpus of Foucault, but instead sought it in fragments, each of which is about the same length as a post on a messaging site.

If Manguso is interested in her own troubled relationship between the act of living and the act of life writing, then I am interested in how her ideas about ongoingness can be used to frame the process of dying and the end-of-life writing that takes place during this time. I am also interested in how ongoingness takes place in relation to digital afterlives and digital footprints. Upon their death, Internet users may leave great quantities of online data, commonly referred to as digital remains, which recall the 'scattered limbs' of IamtheZombie.${ }^{56}$ The living's relationship with the online dead has become subject to greater scrutiny: for example, Jo Bell et $a l$. suggest that 'continuing bonds' can be said to exist between the living and the dead, particularly as online interactions with the deceased can help 'keep them alive'. ${ }^{57}$

When IamtheZombie eventually moved into a hospice, her posts became more sporadic until they finally ceased. In the transition from end-of-life writing to posthumous memorial, subjects themselves participate in their own recollection, even though that participation may become increasingly impaired. By this point, IamtheZombie described her body failing piece-by-piece. What began as breast cancer increasingly encroached on other parts and functions of her body.

\section{Zombie and the Phalanx climb Herceptin Hill}

Evening all. Rat update: There is no doubt that the cats did their duty. Eau de dead rat has started this evening. Unfortunately I will need help getting to it to remove it as it is behind two TV units and I can't move them by myself at the moment.

Earlier this evening I went to stand up to go put the kettle on. My right foot was completely and utterly dead. I fell quite awkwardly twisting the foot and ankle as I did so. I remained on the floor for a few minutes trying to tidy up the contents of the side table that I had knocked over on my way down. Then I maneuvered [sic] myself up into a chair. I stood up and was able to bear weight. The top and side of the foot are very sore but there's no swelling. Walking isn't a lot of fun and I'm using a stick to help. It really was very strange. It was as though something had just turned the foot off and then back on again [...] 
I'm at the hospital tomorrow for my CT scan and if the foot is still painful then I'll pop around to minor injuries and have it checked out.

\section{Bugger, damn and fuck.}

During IamtheZombie's final days in January 2017, Mumsnet users accelerated their posting, with multiple threads beginning in quick succession. Five threads were begun between 10 January and 30 January 2017, posting digital candles and pictures of real candles and toasting IamtheZombie. ${ }^{58}$ Users who had met IamtheZombie in the real world were joined in grief by those who had only followed a few of her recent threads about her cancer treatment. The network thus encompassed anchored and unanchored sociality. In the days and weeks during and after her death, posts proliferated. Mumnset users engaged in spontaneous and simultaneous resurrections of thoughts, reminiscences, memories, recollections and rediscoveries of IamtheZombie's scattered limbs online.

The substitution of the corporeal body with a diasporic digital self is a process that disrupts and diffuses the act of grieving. If someone is not actually dead until the last bonds between living and dead have been severed, then they continue a zombie existence online. Unliving, but not entirely gone. Digital immortality is not true immortality: instead, it provides the potential for a state of ongoingness. Collaboration occurs online between posters and, para-socially, between the living and the dead. How, then, may we frame this kind of digital ongoingness? We have here a kind of memorialisation that is between life and death. If a poster's life writing remains currently unread and dormant, there is nonetheless the possibility of its recovery and resurrection. Threads of posts might be accessed by readers unaware that the author is dead; worse, on some online platforms, illicit cloning of dead users' pages has led to people receiving new friend requests from the deceased's cloned page. These continuations are examples of the complex 'para-social' relationships that can exist between the living and the dead online. ${ }^{59}$

Derrida reminds us 'that ghosts are part of the future and that the modern technology of images [...] like cinematography and telecommunication [...] enhances the power of ghosts and their ability to haunt us' ${ }^{60}$ Thus, in learning to live, we may find it necessary to 'speak of the ghost, indeed to the ghost and with it'. ${ }^{61}$ Technology does, indeed, allow the dead to haunt us. We are encountering zombies, culturally embodied ghosts: those paradoxical beings that exist in the interstitial spaces between alive and dead and human and non-human. The problem of modern bodiless mourning, and the problem of death itself, the failure of the body, collide here. The digital self is a diffuse, diasporic self that is 
neither alive nor dead but instead sits on the threshold of reanimation or resurrection. The ephemerality of online media (broken links, defunct hosting services, obsolete platforms and file formats) only complicates the process further as a broken or missing link can disrupt the recollection of a contributor's digital presence.

Although each online post is in some ways 'timebound', signalled by the date and time stamps and how the posts in a single thread can be arranged chronologically with the most recent listed last, the posts of a single user are nonetheless widely dispersed, and other posters interact with them from different time zones and at different times. The multi-platform and, thus, complex dimensionality of cyberspace means that the connection between posts, threads, sites and forms is not only loose but extends in multiple directions. An additional complication in recovering a user's digital remains occurs when threads across different sites, such as Mumsnet or Reddit, may continue for years or fill up quickly and so lead to the creation of a sequence of threads that can only be discovered through a key word search.$^{62}$ Someone's digital existence may be re-collected by using a search engine, but people's multiple identities online can result in resistance to reunification: if you do not know all the pseudonyms and avatars of a user, and all the sites to which they contributed, then their total recollection becomes much harder, or even impossible.

The digital community of an online forum offers a way of exploring the posthuman idea of selfhood beyond the body, a selfhood in which metaphors of the body substitute for the actual material thing. It hosts a new kind of memorialisation through a diffuse and divergent tissue-like cell culture that is multi-directional, multitemporal, growing in places, shrinking or withering in others, as users click through links to find other threads, acts of replication and deletion either automatic or deliberate. Whilst Maddrell suggests that we map a digital topography of the self online and that we attempt a cartographical understanding of grief and memory, the biological offers a more vital articulation of the parasociality that exists between the living and dead online. These ideas of digital ongoingness as a form of bio-technological interface draw directly from current research in neuroscience that is exploring how digital technology can be used to restore or enhance the human brain's faculties, with special emphasis on memory. At the same time, current computing innovation is increasingly relying on the cellular processes of the brain to provide the next advances in computer memory. In other words, experiments into enhancing human memory function with technology are taking place at the same time as the human neurons involved in memory are being used to enhance technology. This chiasmic overlap demonstrates how the organic and the digital are approaching synthesis and, beyond 
that, a transhuman future in which man and machine may become indistinguishable - also known as reaching singularity.

Research is now taking place in order to achieve and create a true synthesis of man and machine and so, arguably, achieve a state of posthumanism by delaying dying, arresting disease and, ultimately, transcending death. For example, recent neuroscientific research demonstrates that the human brain is becoming altered by technological devices and improvements in biotechnologies, and computer-based technologies are now increasing the likelihood for the development of brain augmentation devices in the next twenty years. These nanosymbiont cognitive enhancers (NCEs) are nanobots which can be programmed to integrate with brain neurons. In theory, NCEs will be able to extend and amplify the reactions of neurons to stimulatory and inhibitory signals and, as such, create an integrative process that would enable more neurons in networks participating in cognitive functions. The NCE would potentially enhance neural processing speed and efficiency in both unhealthy and healthy subjects. ${ }^{63}$

In addition to researchers seeking ways to address brain pathologies, there are more extreme bio-hackers and futurists attempting to overcome the 'problem' of human death. This includes exploring ways to upload digital versions of the brain or to meld man and machine in increasingly sophisticated cyborgised forms. ${ }^{64}$ Forays into digital uploading of the mind tend to focus on how to turn mind into binary and then upload it into cyberspace. The aim of such projects is to be able to reconstruct the human brain in a computer, a fictional idea mooted first in science fiction, for instance Greg Egan's novel Permutation City (1995), but now becoming a reality and being tested on rats. Reaching ever closer towards singularity, the Blue Brain Project has already begun to digitise rat brains and has reported success in reconstructing a section of a rat brain in a computer. This lays the groundwork for potentially being able to reproduce a human brain online that is capable of thought and thus give some semblance of a person continuing to exist beyond the death of the body. The research has been partly supported by the Human Brain Project, a more than $\$ 1$ billion, 10-year European research programme. A separate project at Duke University, led by the neurobiologist Miguel Nicolelis, has resulted in what might be the first working 'brain-to-brain' interface through surgically implanting electrodes in the brains of two groups of rats and wiring them to computers. The rat brain signals travel through the wire into the computer, and then out again into another rat's brain, allowing them to share experiences, sensations and, potentially memories. Nicolelis has also given a TED talk on using the brain signals of a rhesus monkey to control a robotic avatar. 
These kinds of experiments represent expensive and complex explorations into digital uploading and animal-machine interfacing; one could argue, though, that the digital remains of ordinary people, their online life narrative, are a cheap facsimile of this practice. The embedded role of dead users in the architecture of social media platforms means that life is already inseparable from and defined by the conditions of death within digital networks; if current trends continue, within 50 years there will be more dead Facebook-users than living ones. ${ }^{65}$ These virtual hinterlands, and the digital remains scattered across them, open up the idea of human existence beyond the lifespan that we currently understand as located in the body and the mind housed within it. Through imagining these online spaces and the proliferating posts of multiple contributors as a form of cell-based digitality, digital life writing and especially end-of-life writing can thus be characterised as operating as a type of cytoarchitecture. In this way, writers contribute to the formation of an online selfhood, and with it a digital subjectivity, that functions like a series of cells and cell-structures.

The body's physical form is disambiguated in the self's online iterations-but what is created online is a facsimile of the cellular. The term cytoarchitecture refers to a 'group of cells maintaining a mutual organization that is similar to that they take in the organ from which they are derived' ${ }^{66}$ Posts can be imagined as cells, units of self, and, like cells, individual posts are dependent on the production of other posts to keep the thread 'alive'. Cytoarchitecture can thus be used to describe the co-production that takes place on online fora. Cytoarchitectures are formed by groups of cells that retain their architecture so that they appear as a whole structure. In images of the cytoarchitecture of the brain, one can see the multidirectional tendrils-constellatory yet connected, threading between different parts of the brain-that magnetic resonance imaging (MRI) scans and supporting software have been able to map. ${ }^{67}$ The importance of computational and software advances in enabling the innovation in the mapping of animal and human brains merely underscores the symbiosis that exists between the digital and biological. ${ }^{68}$

When mapping the brain, researchers draw on the fact that the study of complex computational systems is facilitated by network maps, such as circuit diagrams; they suggest that such mapping methodology is particularly informative when studying the brain, as the functional role that a brain area fulfils may be largely defined by its connections to other brain areas. ${ }^{69}$ By employing ideas of mapping circuitry in computational systems in order to describe brain functions, the distinction between brain and machine collapses further. Does ever more sophisticated technology for mapping and analysing the brain dictate how we see and understand 
the brain and, in association, our mind and memory? Or are advances in technology largely motivated by our increasing understanding of the most powerful computational source, the brain? So much of how and where consciousness originates and ends is still uncertain.

We may be inclined to think, then, of online posts on fora like Mumsnet as cellular: small cells of life narrative that form a cytoarchitecture that proliferates and is mutable. We could equally conceive of our digital existence as having the potential for posthuman animation of memories and vitality through the creation and transmission of posts. In the synaptic space between posts, identity and memory are transmitted and reanimated. Cellular tissue is hybrid and amorphous, with many diffuse parts that can metastasise. This, in turn, encapsulates the diffuseness and instability of the cyber-self: its construction and proliferation are dependent upon connections to and with others. The cyber-self may also grow, for example, through active posting and interaction, or wither, as when a link becomes defunct. This is akin to the body's cells, which can either replicate through mitosis or meiosis or wither and die, most commonly due to either apoptosis (programmed cell death, which is also described as 'cell suicide'), autophagy (cell death most commonly caused by nutrient deprivation or pathological processes) or necroptosis (cell death caused by trauma or disease). ${ }^{70}$

\section{CONCLUSION}

The idea of cyberspace as a kind of cytoarchitecture helps articulate the ways in which the scattered digital existence of a user's remains continue to be connected in the interstitial spaces of a binary cyber-landscape. The hidden transmission and digital exchange at various interfaces are a cyber equivalent of the body's electrical synapses in which ions flow directly between cells around synaptic circuits. Significantly, it is these electric circuits that have facilitated the bio-hackers' advancements towards the digital uploading of the human mind (in binary) in their attempt to defeat death and remain forever ongoing. Thoughts and conversations of the deceased remain in a state of ongoingness, particularly in the absence of the body and through the disrupted and dislocated grieving process. Online, bodiless mourning is altered by the cytoarchitectural presence of the deceased user's life narrative.

By calling these forms of online life writing a cytoarchitecture, our attention is drawn to the zombified nature of an online user's digital remains. 'Remains' implies cadaverousness. However, cytoarchitectures implies a more vital memory tissue online. The cytoarchitecture of the digital self 
can be dependent on and formed in conjunction with or in response to fellow users' contributions online. Posting on a very old thread is called reanimating a 'zombie' thread, a process known by the neologism necroing. ${ }^{71}$ And so the possibility of reanimation does, in some way, allow a part of us to defeat death and to achieve a kind of digital immortality, even if it is a zombified one. A broken or missing link-like decaying tissue-may erode the comprehensiveness and ease of recollection and create space for the disappearance or dissolution of self; yet the tissue of IamtheZombie's posts also integrates with those of others to form the cytoarchitecture that transmits her end-of-life writing into digital memory.

Since her death in 2017, there has been one final digital materialisation, or preservation, of IamtheZombie: the gin bottle emoticon. In memoriam to IamtheZombie, Mumsnet created a new gin bottle emoticon for users, which is now used across the entire chat forum-often in ignorance of its origin and initial meaning. The gin bottle synecdochically represents an aspect of IamtheZombie's taste and enthusiasms, as it was made to represent her love of gin and to recall the digital sociality of the threads, which were notable for their wry humour and warmth and included celebratory cyber-toasts with cyber-drinking of gin that continued online long after IamtheZombie was physically able to drink alcohol. $^{72}$

Today's online explorers may search for IamtheZombie through Mumsnet's site search-bar, and her compelling narrative-sick and well, ironic and kind, significant and silly_ can be collated on a single page. The pieces of her story may be algorithmically stitched back together. The ongoingness of the self takes place through the reanimation of threads and the ways in which IamtheZombie is knowingly or unknowingly referenced by other users. Conceiving of digital remains as functioning like digital cytoarchitectures offers a different kind of remembrance and ongoingness to the diary or old letter being rediscovered, and operates differently from material forms of bodiless remembrance found in the real world, such as spontaneous shrines or formal memorials like the Cenotaph. Online, that which may be re-membered exists in the cytoarchitecture of virtual space, which in this case, includes the scattered life writing of IamtheZombie and her interlocutors. Cytoarchitecture is, therefore, another tool to add to Smith and Watson's digital 'toolkit' or 'toolbox'. ${ }^{73}$ The diverse digital cells of life narrative form a tissue that animates the threads. Users might insert the gin bottle emoticon into their posts: sometimes, users' inclusion of the gin bottle emoticon in their posts results in unexpected resurrections of IamtheZombie's story in brief communal acts of recollection and remembrance. Thus, every time a user posts a pictogrammic gin bottle, 
IamtheZombie's history may be recalled. The pictogram is part of IamtheZombie's ongoingness. For example, on a mundane thread complaining about a British cooking show, a spontaneous discussion of the connection between IamtheZombie and the gin bottle takes place. It is a surprising and incidental recollection, filled with warmth, during an otherwise unrelated online conversation: a memory suddenly triggered. Online, this momentary recollection can and does lead other users to track down more of IamtheZombie's words across Mumsnet.

IamtheZombie once typed goodnight, fiends, and the reader can imagine that the finger which slipped over the letter $\mathrm{R}$ was complicit in her digital conspiracy to haunt and beguile. Her digital existence is a zombie existence. Sewn together from cellular pieces of text, the self and its history are reconstituted from posts and parts that populate the hinterland of the social media forum Mumsnet. ${ }^{74}$ What can be found by entering IamtheZombie's username into the search bar on Mumsnet is a catalogue of her comments and conversations stitched together by an algorithm. In doing so, recollection takes place: a re-membering of her separate pieces online. Indeed, if a reader of this article were to seek IamtheZombie online, they too would find her and could, if they wish, reanimate a thread in new and lively ways.

[IamtheZombie] Sat 30-Mar-13 17:24:37

Zombie speaks in the third person. But, I am Zombie and that is my experience.

\section{ACKNOWLEDGEMENTS}

This essay is dedicated to IamtheZombie, Candy Orr, who, before she died in 2017, gave her consent and discussed the possibility of collaborating with the author of this work. With thanks to her son, Jason Brown, who has continued to support this work, and to MumsnetHQ for giving permission for Candy Orr's posts to be reprinted here.

\section{WORKS CITED}

Allen, Gary L. (ed.). Human Spatial Memory: Remembering Where. New Jersey: Lawrence Erlbaum, 2004.

Amunts, K., A. Schleicher and K. Zilles. 'Cytoarchitecture of the Cerebral Cortex-More than Localization.' NeuroImage 37 (2007) 1061-1065.

Amunts, K. and K. Zilles. 'Architectonic Mapping of the Human Brain beyond Brodmann.' Neuron 88 (2015) 1086-1107. 
Baena, Rosalia. Transculturing Auto/Biography: Forms of Life Writing. Abingdon: Routledge, 2013.

Becker, Barbara. 'Cyborgs, Agents and Transhumanist: Crossing Traditional Borders of Body and Identity in the Context of New Technology.' Leonardo 33:5 (2000) 361-365.

Bell, J., L. Bailey and D. Kennedy. "We Do it to Keep Him Alive": Bereaved Individuals' Experiences of Online Suicide Memorials and Continuing Bonds.' Mortality 20:4 (2015) 375-389.

Berlant, Lauren. The Female Complaint: The Unfinished Business of Sentimentality in American Culture. North Carolina: Duke University Press, 2008.

Bishop, Kyle William. American Zombie Gothic: The Rise and Fall (and Rise) of the Walking Dead in Popular Culture. Jefferson, MC: McFarland, 2010.

Boyd, D. and N. Ellison. 'Social Network Sites: Definition, History, and Scholarship.' Journal of Computer-Mediated Communication 13 (2008) 210-230.

Boon, Kevin. 'Ontological Anxiety Made Flesh: The Zombie in Literature, Film and Culture.' Monsters and the Monstrous (2007) 33-43.

Brant, Clare. 'Imaginative Agency: New Possibilities.' European Journal of Life Writing 8 (2019) $143-170$.

Bursch, W., A. Ellinger, C. Gerner, U. Fröhwein and R. Schulte-Hermann. 'Programmed Cell Death (PCD). Apoptosis, Autophagic PCD, or Others?' Annals of the New York Academy of Sciences 926 (2000) 1-12.

Calzati, Stefano and Roberto Simanowski. 'Self-Narratives on Social Networks: Trans-Platform Stories and Facebook's Metamorphosis into a Postmodern Semiautomated Repository.' Biography 41:1 (2018) 24-47.

Cann, Candi K. Virtual Afterlives: Grieving the Dead in the Twenty-First Century. Lexington: The University Press of Kentucky, 2014.

Chun, Wendy Hui Kyong. Programmed Visions: Software and Memory. Cambridge, Massachusetts: MIT, 2011.

Clymer, Lorna. 'Graved in Tropes: The Figural Logic of Epitaphs and Elegies in Blair, Gray, Cowper, and Wordsworth.' ELH 62:2 (1995) 347-386.

Couldry, Nick. 'The Social Foundations of Future Digital Politics.' In: Stephen Coleman and Deen Freelon (eds.), Handbook of Digital Politics. Cheltenham: Edward Elgar, 2015.

Couser, G. Thomas. 'Autopathography: Women, Illness, and Lifewriting.' a/b: Auto/Biography Studies 6:1 (1991) 65-75.

Couser, G. Thomas. Recovering Bodies: Illness, Disability, and Life Writing. Madison: U of Wisconsin P, 1997.

Couser, G. Thomas. 'Body Language: Illness, Disability, and Life Writing.' Life Writing 13:1 (2016) 3-10.

Cover, Rob. 'Becoming and Belonging: Performativity, Subjectivity, and the Cultural Purposes of Social Networking.' In: Anna Poletti and Julie Rak (eds.), Identity Technologies: Constructing the Self Online. Madison: University of Wisconsin Press, 2014.

Dendle, Peter. 'Zombie Movies and the "Millennial Generation".' In: Deborah Christie and Sarah Juliet Lauro (eds.), Better Off Dead: The Evolution of the Zombie as Post-human. New York: Fordham University Press, 2011.

Derrida, Jacques. Spectres of Marx: The State of the Debt, the Work of Mourning and the New International. Trans. Peggy Kamuf. New York: Routledge, 1994.

Derrida, Jacques. The Work of Mourning. Trans. Pascale-Anne Brault and Michael Naas. Chicago: University of Chicago Press, 2001.

Derrida, Jacques. Quoted in Ghost Dance. Dir. Ken McMullen. London: Mediabox Limited, 2008.

Doyle, Richard. On Beyond Living: Rhetorical Transformations of the Life Sciences. Stanford: Stanford University Press, 1997. 
Feigel, Lara and Max Saunders. 'Writing Between the Lives: Life Writing and the Work of Mediation.' Life Writing 9:3 (2012) 241-248.

Frank, Arthur W. The Wounded Storyteller: Body, Illness, and Ethics. Chicago: University of Chicago Press, 1995.

Gamburd, Michele Ruth. Breaking the Ashes: The Culture of Illicit Liquor in Sri Lanka. New York: Cornell University Press, 2008.

de Garine, I. and V. de Garine (eds.). Drinking: Anthropological Approaches. New York: Berghahn Books, 2001.

Gray, Mary L. 'Negotiating Identities/Queering Desires: Coming Out Online and the Remediation of the Coming-Out Story.' In: Anna Poletti and Julie Rak (eds.), Identity Technologies: Constructing the Self Online. Madison: University of Wisconsin Press, 2014.

Gubbels, Marc-Jan, Michael White and Tomasz Szatanek. 'The Cell Cycle and Toxoplasma Gondii Cell Division: Tightly Knit or Loosely Stitched?' International Journal for Parasitology 38:12 (2008) 1343-1358.

Hasselmo, Michael E. How We Remember: Brain Mechanisms of Episodic Memory. Massachusetts: MIT Press, 2012.

Hubner, Laura, Marcus Leaning and Paul Manning. The Zombie Renaissance in Popular Culture. Basingstoke: Palgrave Macmillan, 2014.

Inglis, K.S. 'Entombing Unknown Soldiers: From London and Paris to Baghdad.' History and Memory 5:2 (1993) 7-31.

Karppi, Tero. 'Death Proof: On the Biopolitics and Noopolitics of Memorializing Dead Facebook Users.' Culture Machine 14 (2013) 1-20.

Kasket, Elaine. All the Ghosts in the Machine: Illusions of Immortality in the Digital Age. London: Robinson, 2019.

Kennedy, Helen. 'Beyond Anonymity, or Future Directions for Internet Identity Research.' In: Anna Poletti and Julie Rak (eds.), Identity Technologies: Constructing the Self Online. Madison: University of Wisconsin Press, 2014.

Kiernan, Hugh. "'Ah, But I was so much Older Then, I'm Younger than that Now": Cancer and a Virtual Relationship.' Life Writing 13 (2016) 1-11.

Lavoie, Brian and Lorcan Dempsey. 'Thirteen Ways of Looking at... Digital Preservation.' D-Lib Magazine 10:7/8 (2004).

Lingel, J. 'The Digital Remains: Social Media and Practices of Online Grief.' The Information Society 29:3 (2013) 190-195.

Maddrell, Avril. 'Mapping Grief. A Conceptual Framework for Understanding the Spatial Dimensions of Bereavement, Mourning and Remembrance.' Social E Cultural Geography 17:2 (2016) 166-188.

Manguso, Sarah. Ongoingness: The End of a Diary. London: Picador, 2018.

McNeill, Laurie. 'There Is No "I" in Network: Social Networking Sites and Posthuman Auto/ Biography.' Biography 35:1 (2012) 65-82.

Micalizzi, Alessandra. 'Cyber-Self: In Search of a Lost Identity?' In: Julie Rak and Anna Poletti (eds.), Identity Technologies: Producing Online Selves. University of Wisconsin Press, 2013, 217-229.

Morrison, Aimée. “'What's on Your Mind?”: The Coaxing Affordances of Facebook's Status Update.' In: Julie Rak and Anna Poletti (eds.), Identity Technologies: Producing Online Selves. University of Wisconsin Press, 2013, 112-132.

Myles, David and Florence Millerand. 'Mourning in a "Sociotechnically Acceptable Manner": A Facebook Case Study.' In: Andrea Hajek, Christine Lohmeier, Christian Pentzold (eds.), Memory in a Mediated World: Remembrance and Reconstruction. New York: Springer, 2016, 229-243.

van der Nagel, Emily. 'From Usernames to Profiles: The Development of Pseudonymity in Internet Communication.' Internet Histories 1:4 (2017) 312-331. 
Nakamura, Lisa. 'Cyberrace.' In: Anna Poletti and Julie Rak (eds.), Identity Technologies: Constructing the Self Online. Madison: University of Wisconsin Press, 2014.

O'Connell, Mark. To Be a Machine: Adventures Among Cyborgs, Utopians, Hackers, and the Futurists Solving the Modest Problem of Death. New York: Doubleday, 2017.

Öhman, Carl J. and David Watson. 'Are the Dead Taking over Facebook? A Big Data Approach to the Future of Death Online.' Big Data E' Society 6:1 (2019) 1-13.

Page, Ruth and Bronwen Thomas (eds.). New Narratives: Stories and Storytelling in the Digital Age. Nebraska: University of Nebraska Press, 2011.

Pedersen S. "'It Took a Lot to Admit I Am Male on Here." Going Where Few Men Dare to Tread: Men on Mumsnet.' In: E. Thorsen, H. Savigny, J. Alexander, D. Jackson (eds.), Media, Margins and Popular Culture. London: Palgrave Macmillan, 2015, 249-261.

Pedersen, S. and J. Smithson. 'Supporting or Stressing Out? A Study of Membership, Activity and Interactions in an Online Parenting Community.' In: R. Taiwo (ed.), Handbook of Research on Discourse Behavior and Digital Communication. Hershey, PA: IGI Global, 2010, 88-103.

Pedersen, S. and J. Smithson. 'Mothers with Attitude-How the Mumsnet Parenting Forum Offers Space for New Forms of Femininity to Emerge Online.' Women's Studies International Forum 38 (2013) 97-106.

Plato. 'The Collected Dialogues of Plato.' In: Edith Hamilton and Huntington Cairns (eds.). New Jersey: Princeton University Press, 1961.

Ploug, Thomas. Ethics in Cyberspace: How Cyberspace May Influence Interpersonal Interaction. Netherlands: Springer, 2009.

Phillips, Jeffrey, A.S. Greenberg, J.A. Pyles, S.K. Pathak, M. Behrmann, W. Schneider and M.J. Tarr. 'Co-analysis of Brain Structure and Function using fMRI and Diffusion-weighted Imaging.' Journal of Visualized Experiments 69:10 (2012) 3791-4125.

Poletti, Anna and Julie Rak (eds.). Identity Technologies: Constructing the Self Online. Madison: University of Wisconsin Press, 2014.

Poletti, Anna. 'Periperformative Life Narrative: Queer Collages.' GLQ22:3 (2016) 359-379.

Ressel, Lorenzo. Normal Cell Morphology in Canine and Feline Cytology: An Identification Guide. Hobeken: John Wiley \& Sons, 2017.

Roberts, Krista. 'Digital Archives, Text Encoding Initiative, and Relationality: Locating Digital Life Writing | Writing to the Future.' a/b: Auto/Biography Studies 32:2 (2017) 411-413.

Rosenzweig, Mark. 'Regulation of Cortical Function in Memory: Introduction.' In: James L. McGaugh, Norman M. Weinberger and Gary Lynch (eds.), Brain Organization and Memory: Cells, Systems, and Circuits. Oxford: Oxford University Press, 1992, 177-184.

Saniotis, Arthur, Henneberg Maciej and Sawalma Abdul-Rahman. 'Integration of Nanobots into Neural Circuits as a Future Therapy for Treating Neurodegenerative Disorders.' Frontiers in Neuroscience, 12:153 (2018).

Simanowski, Roberto. Facebook Society: Are We Sharing Ourselves into Oblivion? Trans. Susan H. Gillespie. Columbia University Press, 2018.

Simanowski, Roberto. 'Instant Selves: Algorithmic Autobiographies on Social Network Sites.' New German Critique 139:1 (2017) 233-244.

Smith, Sidonie and Julia Watson. Reading Autobiography: A Guide for Interpreting Life Narratives. Minnesota: University of Minnesota Press, 2001.

Smith, Sidonie and Julia Watson. 'Virtually Me: A Toolbox about Online Self-Presentation.' In: Anna Poletti and Julie Rak (eds.), Identity Technologies: Constructing the Self Online. Madison: University of Wisconsin Press, 2014, 70-99.

Socolovsky, Maya. 'Cyber-Spaces of Grief: Online Memorials and the Columbine High School Shootings.' JAC 24:2 (2004) 467-489.

Seo, Hyunjin, J. Brian Houston, Leigh Anne Taylor Knight, Emily J. Kenney and Alexandra B. Inglish. 'Teens' Social Media Use and Collective Action.' New Media Eo Society 16:16 (2014) 883-902. 
Shaw, Julia. The Memory Illusion: Remembering, Forgetting, and the Science of False Memory. London: Random House, 2016.

Sherlock, A. 'Larger than Life: Digital Resurrection and the Re-enchantment of Society.' The Information Society 12 Big Data E Society 29:3 (2013) 164-176.

Sontag, Susan. Illness as Metaphor and Aids and Its Metaphors. New York: Farrar, Straus and Giroux, 1979.

Swan, Liz Stillwaggon and Joshua Howard. 'Digital Immortality: Self or 0010110.' International Journal of Machine Consciousness 4:1 (2012) 245-256.

Sweatt, J. David. Mechanisms of Memory. New York: Academic Press, 2009.

Trumpener, Katie. 'Memories Carved in Granite: Great War Memorials and Everyday Life.' PMLA 115:5 (2000) 1096-1103.

Whitlock, Gillian and Anna Poletti. 'Self-Regarding Art.' Biography, 31:1 (2008) v-xxiii.

Wu, Cynthia. 'Marked Bodies, Marking Time: Reclaiming the Warrior in Audre Lorde's The Cancer Journals.' a/b: Auto/Biography Studies 17:2 (2002) 245-261.

Zhao, S., S. Grasmuck and J. Martin, 'Identity Construction on Facebook: Digital Empowerment in Anchored Relationships.' Computers in Human Behavior 24:5 (2008) 1816-1836.

\section{ABOUT THE AUTHOR}

Emma Newport is a lecturer at the University of Sussex. As a member of the Centre for Life History and Life Writing Research, Emma has published a chapter on 'Brief Encounters: Curating GIFs, Memes and Social Media for Short Story LifeWriting' in New and Experimental Approaches to Writing Lives, edited by Jo Parnell (2019). Emma is the founder and director of Sussex Writes, a programme that uses life writing and creative writing to build communities amongst the university, school students and local citizens. E-mail: e.newport@sussex.ac.uk.

\section{NOTES}

1 Manguso, Sarah. Ongoingness: The End of a Diary. London: Picador, 2018 (83).

2 On epitaphs and unsilencing the dead, see Clymer, Lorna. 'Graved in Tropes: The Figural Logic of Epitaphs and Elegies in Blair, Gray, Cowper, and Wordsworth.' ELH 62:2 (1995) 347-386.

3 Cann, Candi K. Virtual Afterlives: Grieving the Dead in the Twenty-First Century. Lexington: The University Press of Kentucky, 2014 (33).

4 Idem (34).

5 Thucydides gives one of the earliest written accounts of using empty coffins in Athenian ceremonies to commemorate and mourn soldiers lost in the wars against Sparta. See Inglis, K.S. 'Entombing Unknown Soldiers: From London and Paris to Baghdad.' History and Memory 5:2 (1993) 8.

6 Trumpener, Katie. 'Memories Carved in Granite: Great War Memorials and Everyday Life.' PMLA 115:5 (2000) 1096-1103.

7 Idem (1097).

8 Cann, Candi K., 2014 (34).

9 See also Socolovsky, Maya. 'Cyber-Spaces of Grief: Online Memorials and the Columbine School Shootings.' JAC 24:2 (2004) 467-489; Karppi, Tero. 'Death Proof: On the 
Biopolitics and Noopolitics of Memorializing Dead Facebook Users.' Culture Machine 14 (2013) 1-20.

10 Baena, Rosalia. Transculturing Auto/Biography: Forms of Life Writing. Abingdon: Routledge, 2013.

11 Morrison, Aimée. “What's on Your Mind?”: The Coaxing Affordances of Facebook's Status Update.' In: Julie Rak and Anna Poletti (eds.), Identity Technologies: Producing Online Selves. University of Wisconsin Press, 2013 (112).

12 Poletti, Anna. 'Periperformative Life Narrative: Queer Collages.' GLQ 22:3 (2016) 359-362.

13 Lavoie B. and Dempsey L. 'Thirteen Ways of Looking at... Digital Preservation.' D-Lib Magazine 10:7-8 (2004) 229.

14 Maddrell, Avril. 'Mapping Grief. A Conceptual Framework for Understanding the Spatial Dimensions of Bereavement, Mourning and Remembrance.' Social E Cultural Geography 17:2 (2016) 166-188.

15 Amunts, K., A. Schleicher and K. Zilles. 'Cytoarchitecture of the Cerebral CortexMore than Localization.' NeuroImage 37 (2007) 1061.

16 Sweatt, J. David. Mechanisms of Memory. New York: Academic Press, 2009 (247); Rosenzweig, Mark. 'Regulation of Cortical Function in Memory.' In: James L. McGaugh, Norman M. Weinberger and Gary Lynch (eds.), Brain Organization and Memory: Cells, Systems, and Circuits. Oxford: Oxford University Press, 1992 (177-298).

17 Ploug, Thomas. Ethics in Cyberspace: How Cyberspace May Influence Interpersonal Interaction. Netherlands: Springer, 2009 (66); Chun, Wendy. Programmed Visions: Software and Memory. Cambridge, Massachusetts: MIT, 2011 (137-174).

18 Doyle, Richard. On Beyond Living: Rhetorical Transformations of the Life Sciences. Stanford: Stanford University Press, 1997 (2-3).

19 Idem (5).

20 Idem (4).

21 Chun, Wendy, 2011 (105)

22 Idem $(59-96,133,135)$.

23 See Poletti, Anna and Julie Rak (eds.). Identity Technologies: Constructing the Self Online. Madison: University of Wisconsin Press, 2014; Simanowski, Roberto. Facebook Society: Are We Sharing Ourselves into Oblivion? Trans. Susan H. Gillespie. Columbia University Press, 2018.

24 Roberts, Krista. 'Digital Archives, Text Encoding Initiative, and Relationality: Locating Digital Life Writing | Writing to the Future.' a/b: Auto/Biography Studies32:2 (2017) 411-413.

25 McNeill, Laurie. "There is No "I" in Network: Social Networking Sites and Posthuman Auto/biography.' Biography 35:1 (2012) 73. SNSs such as Facebook are defined as 'webbased services that allow individuals to (1) construct a public or semi-public profile within a bounded system, (2) articulate a list of other users with whom they share a connection, and (3) view and traverse their list of connections and those made by others within the system'. See Boyd, D. and N. Ellison. 'Social Network Sites: Definition, History, and Scholarship.' Journal of Computer-Mediated Communication 13 (2008) 211.

26 McNeill, 2012 (74).

27 Whitlock, Gillian and Anna Poletti. 'Self-Regarding Art.' Biography 31:1 (2008) xv.

28 Idem (xiv).

29 Morrison, Aimée, 2013 (112).

30 See Kennedy, Helen. 'Beyond Anonymity, or Future Directions for Internet Identity Research (25-41); Lisa Nakamura 'Cyberrace' (42-54); Rob Cover. 'Becoming and Belonging: Performativity, Subjectivity, and the Cultural Purposes of Social Networking' (55-69); Mary L. Gray. 'Negotiating Identities/Queering Desires: Coming Out Online and the Remediation of the Coming-Out Story' (167-197). In: Poletti and Rak, 2014. 
31 Zhao, S., S. Grasmuck and J. Martin. 'Identity Construction on Facebook: Digital Empowerment in Anchored Relationships.' Computers in Human Behavior 24:5 (2008) 1816-1836.

32 Kiernan, Hugh. "Ah, but I was so much Older Then, I'm Younger than that Now”: Cancer and a Virtual Relationship.' Life Writing 13 (2016) 1-11.

33 Micalizzi, Alessandra. 'Cyber-Self: In Search of a Lost Identity?’ In: Julie Rak and Anna Poletti (eds.), Identity Technologies: Producing Online Selves. University of Wisconsin Press, 2013, 217-228.

34 Sontag, Susan. Illness as Metaphor and Aids and Its Metaphors. New York: Farrar, Straus and Giroux, 1979 (57-58).

35 Frank, Arthur W. The Wounded Storyteller: Body, Illness, and Ethics. Chicago: University of Chicago Press, 1995 (9).

36 “'interstitial”, adj. and n.' OED Online. March 2020. Oxford University Press. https:// www.oed.com/view/Entry/98356? redirectedFrom=interstitial. Date accessed: 06 May 2020.

37 Their italics; Feigel, Lara and Max Saunders. 'Writing Between the Lives: Life Writing and the Work of Mediation.' Life Writing 9:3 (2012) (241).

38 Wu, Cynthia. 'Marked Bodies, Marking Time: Reclaiming the Warrior in Audre Lo'de's The Cancer Journals.' a/b: Auto/Biography Studies 17:2 (2002) 256.

39 E.g. Socrates on death in Plato, The Collected Dialogues of Plato. Edith Hamilton and Huntington Cairns (eds.), New Jersey: Princeton University Press, 1961, 40-98.

40 See Berlant, Lauren. The Female Complaint: The Unfinished Business of Sentimentality in American Culture. North Carolina: Duke University Press, 2008. On Mumsnet, see Pedersen S. "It Took a Lot to Admit I Am Male on Here." Going Where Few Men Dare to Tread: Men on Mumsnet.' In: E. Thorsen, H. Savigny, J. Alexander, D. Jackson (eds.), Media, Margins and Popular Culture. London: Palgrave Macmillan, 2015, 249-261; Pedersen, S. and J. Smithson. 'Supporting or Stressing Out? A Study of Membership, Activity and Interactions in an Online Parenting Community.' In: R. Taiwo (ed.), Handbook of Research on Discourse Behavior and Digital Communication. Hershey, PA: IGI Global (2010), 88-103; Pedersen, S. and J. Smithson. 'Mothers with Attitude-How the Mumsnet Parenting Forum Offers Space for New Forms of Femininity to Emerge Online.' Women's Studies International Forum 38 (2013) 97-106.

41 van der Nagel, Emily. 'From Usernames to Profiles: the Development of Pseudonymity in Internet Communication.' Internet Histories 1:4 (2017) 312-331.

42 For discussion of abusive trolling, see Brant, Clare. 'Imaginative Agency: New Possibilities.' European Journal of Life Writing 8 (2019) 143-170.

43 Such use of emojis is not limited to Mumsnet.

44 Couser, G. Thomas. 'Body Language: Illness, Disability, and Life Writing.' Life Writing 13:1 (2016) 6 .

45 In addition to her use of Mumsnet, Candy Orr maintained a Facebook page and a Twitter account; the latter included a zombie reference in her Twitter handle. All three social media sites reveal interconnection with one another; some connections are obvious and others obscure.

46 OFRS is the Oh Fuck Rucksack, an acronym used on Mumsnet thread for 'preppers': people who are interested in preparing, or 'prepping', for real crises (pandemics, world war, global ecological disaster) or imaginary disasters (zombie apocalypse).

47 Dendle, Peter. 'Zombie Movies and the "Millennial Generation”' In: Deborah Christie and Sarah Juliet Lauro (eds.), Better Off Dead: The Evolution of the Zombie as Post-human. New York: Fordham University Press, 2011, 175.

48 'Zombie code' is a code that is not live-or alive-because it is not runnable. As computer code evolves, either manually or algorithmically, sections become redundant as the 
live code changes around the zombie code to the point that the zombie code becomes totally unrelated to the live one; however, when developers come across this zombie code, they assume there must be a reason it exists and so leave it.

49 See Bishop, Kyle William. American Zombie Gothic: The Rise and Fall (and Rise) of the Walking Dead in Popular Culture. Jefferson, MC: McFarland, 2010; Hubner, Laura. Marcus Leaning and Paul Manning. The Zombie Renaissance in Popular Culture. Basingstoke: Palgrave Macmillan, 2014; Boon, Kevin. 'Ontological Anxiety Made Flesh: The Zombie in Literature, Film and Culture.' In: Monsters and the Monstrous (2007), 33-43.

50 HER2-positive breast cancer tests positive for a protein called human epidermal growth factor receptor 2 (HER2), which promotes the growth of cancer cells. HER2-positive breast cancers tend to be more aggressive than other types of breast cancer.

51 Derrida, Jacques. The Work of Mourning. Trans. Pascale-Anne Brault and Michael Naas. Chicago: University of Chicago Press, 2001 (28).

52 Ibidem.

53 Idem (88).

54 Manguso, 2018 (8).

55 Ibidem.

56 Lingel, J. 'The Digital Remains: Social Media and Practices of Online Grief.' The Information Society 29:3 (2013) 190-195.

57 Bell J., L. Bailey and D. Kennedy. "We do it to keep him alive": Bereaved Individuals' Experiences of Online Suicide Memorials and Continuing Bonds.' Mortality 20:4 (2015) 376.

58 E.g. Zombie has her hospital bed so the Phalanx had a sleep over; Zombie - the old lush needs us, so rally around you Phalanxers; Keep the home fires burning for Zombie.

59 Sherlock, A. 'Larger than Life: Digital Resurrection and the Re-enchantment of Society.' The Information Society 12 Big Data EO Society 29:3 (2013) 164-176.

60 Derrida, Jacques, as quoted in Ghost Dance. Dir. Ken McMullen. London: Mediabox Limited, 2008.

61 Derrida, Jacques. Spectres of Marx: The State of the Debt, the Work of Mourning and the New International. Trans. Peggy Kamuf. New York: Routledge, 1994 (xviii); see also Kasket, Elaine. All the Ghosts in the Machine: Illusions of Immortality in the Digital Age. London: Robinson, 2019.

62 E.g. the long-running Archers threads on Mumsnet are quite rigorously managed by their contributors, who number each new thread; these threads are all collated under one topic page, 'Radio Addicts'.

63 Saniotis, Arthur, Henneberg Maciej and Sawalma Abdul-Rahman. 'Integration of Nanobots Into Neural Circuits as a Future Therapy for Treating Neurodegenerative Disorders.' Frontiers in Neuroscience 12:153 (2018).

64 O'Connell, Mark. To Be a Machine: Adventures Among Cyborgs, Utopians, Hackers, and the Futurists Solving the Modest Problem of Death. New York: Doubleday, 2017; Swan, Liz Stillwaggon and Joshua Howard. 'Digital Immortality: Self or 0010110.' International Journal of Machine Consciousness 4:1 (2012) 245-256; Becker, Barbara. 'Cyborgs, Agents and Transhumanist: Crossing Traditional Borders of Body and Identity in the Context of New Technology.' Leonardo 33:5 (2000) 361-365.

65 Öhman, Carl J. and David Watson. 'Are the Dead Taking over Facebook? A Big Data Approach to the Future of Death Online.' Big Data E Society 6:1 (2019) 1-13; Myles, David and Florence Millerand. 'Mourning in a "Sociotechnically Acceptable Manner": A Facebook Case Study.' In: Andrea Hajek, Christine Lohmeier, Christian Pentzold (eds.), Memory in a Mediated World: Remembrance and Reconstruction. New York: Springer, 2016, 229-243.

66 Ressel, Lorenzo. Normal Cell Morphology in Canine and Feline Cytology: An Identification Guide. Hobeken: John Wiley \& Sons, 2017 (139). 
67 Cytoarchitecture describes the spatial distribution patterns of cell bodies, such as neuronal cells in the brain; cytoarchitectonics is the scientific study of the cellular composition of a bodily structure. Techniques used to study the neuronal composition of the brain may include, though are not limited to, imaging and optical methods; twodimensional and three-dimensional quantitative architectonics; and high-performance computing, including big data analysis. See Amunts, K. and K. Zilles. 'Architectonic Mapping of the Human Brain beyond Brodmann.' Neuron 88 (2015) 1086-1107.

68 Ibidem.

69 Phillips, Jeffrey et al. 'Co-analysis of Brain Structure and Function using fMRI and Diffusion-weighted Imaging.' Journal of Visualized Experiments. 69:10 (2012) 3791-4125. Biologists use the metaphor of threading and knitting to describe certain types of mitosis and cytokinesis, which are forms of cell production. For example, researchers questioned whether the cell cycle and process of cell division in toxoplasma gondii, a single-celled parasite, were 'tightly knit or loosely stitched'. See Gubbels, Marc-Jan, Michael White and Tomasz Szatanek. 'The Cell Cycle and Toxoplasma Gondii Cell Division: Tightly Knit or Loosely Stitched?' International Journal for Parasitology 38:12 (2008) 1343-1358. That the word 'thread' both describes cellular processes and provides a tangible base for a model of cell-culture systems points to the aptness of thinking relating digital threads to cell cultures.

70 On cell death, see Bursch, W. et al. 'Programmed Cell Death (PCD). Apoptosis, Autophagic PCD, or Others?' Annals of the New York Academy of Sciences 926 (2000) 1-12.

71 During a discussion of the problem of zombie threads on Mumsnet in 2012, some posters asked, ironically, whether IamtheZombie had been consulted on the matter.

72 Drinking alcohol as part of the funeral process has been identified in, but not limited to, European, Northern American, Latin American, African and Pacific cultures (I. de Garine and V. de Garine, 2001). Drinking alcohol at funerals can also occur in cultures that otherwise prohibit alcohol consumption; see Gamburd, Michele Ruth. Breaking the Ashes: The Culture of Illicit Liquor in Sri Lanka. New York: Cornell University Press, 2008 (96).

73 Smith, Sidonie and Julia Watson. Reading Autobiography: A Guide for Interpreting Life Narratives. Minnesota: University of Minnesota Press, 2001 (165); Smith and Watson. 'Virtually Me: A Toolbox about Online Self-Presentation.' In: Anna Poletti and Julie Rak (eds.), Identity Technologies: Constructing the Self Online. Madison: University of Wisconsin Press, 2014, 70.

74 Mumsnet-users have created the 'Woolly Hugs' knitting group, making blankets for those in palliative care or for families recently bereaved. The craftswomen connect online and then work individually on a knitted piece of a blanket before sending it in to one person to make a single blanket from the pieces. IamtheZombie contributed generously and enthusiastically to making blankets for women with breast cancer; the Woolly Hugs group then went on to make a blanket of remembrance for IamtheZombie's son in the USA. 'Stitching together' is thus literal and metaphorical. As a domestic craft and traditionally female skill rather than the medical stitching of some modern Dr Frankenstein, the blanket formed creates a physical synecdoche of the diseased. The colours and patterns aim to reflect the person it represents. At the same time, via the virtual platform of social media, the blanket's instigation, progress and completion are coordinated and recorded online, leaving a digital account of the many online contributors. The virtual knitting community commemorates the dying and the dead through their conversations online and through the creation of the material blanket. 